\title{
SIX HIT TREADMILL SESSIONS IMPROVE LIPID OXIDATION AND VENTILATORY THRESHOLD INTENSITIES
}

\author{
SEIS SESSÕES DE HITEM ESTEIRA AUMENTAM A OXIDAÇÃO DE LIPIDIOS E LIMIARES VENTILATÓRIOS
}

\author{
SEIS SESIONES DE HIT EN CINTA DE CORRER AUMENTAN LA OXIDACIÓN DE LIIPIDOS Y \\ UMBRALES VENTILATORIOS
}

Marcelo Luis Marquezi

(Physical Education Professional)

Camila Fabiana Martins Agostinho (Physical Education Professional)

Fabio Rocha de Lima' ${ }^{1}$

(Physical Education Professional)

Juliana Monique Lino Aparecido

(Physiotherapist)

Marcelo Santin Cascapera ${ }^{2}$

(Physician)

1. Universidade Cidade de São

Paulo (UNICID), Physical Education

Research Laboratory (LAPEF),

São Paulo, Brazil.

2. Santa Casa de Misericórdia de

São Paulo, São Paulo, SP, Brazil.

\section{Correspondência:}

Marcelo Luis Marquezi

Rua Cesário Galeno, 432/448,

Tatuapé, São Paulo, SP, Brazil.

03071-000

mlmqzz@gmail.com

\begin{abstract}
Introduction: High-intensity interval training (HIT) has been used as an alternative to cardiorespiratory training performed continuously at submaximal intensity and over long periods. Objectives: Propose a treadmill HIT protocol and verify the influence of six HIT sessions with this protocol on ventilatory anaerobic thresholds (VATs) and substrate oxidation pattern during submaximal continuous exercise (SCE). Methods: Fifteen sporadically active subjects underwent maximal progressive testing before and after six HIT treadmill running sessions to determine peak oxygen uptake $\left(\mathrm{VO}_{2 \text { peak }}\right)$, peak velocity $\left(\mathrm{V}_{\text {peak }}\right)$, and VATs followed by SCE to determine lipid (LIPOx) and carbohydrate (CHOox) oxidation rates. The HIT sessions consisted of eight sets of $60 \mathrm{~s}$ at $100 \% \mathrm{~V}$ peak, interspersed with $75 \mathrm{~s}$ of passive recovery between sets and a $48 \mathrm{~h}$ interval between sessions. Results: Our results showed increases in VAT intensities of 4.4\% for VAT1 and 8.8\% for VAT2, a decrease of 12.8\% in CHOox and an increase of $23.7 \%$ for LIPox; accordingly, the relative energy derived from LIPox was $20.3 \%$ higher after the training period. $V_{\text {peak }}$ was $\sim 15 \mathrm{~km} / \mathrm{h}$, producing intensities corresponding to $\sim 84 \% \mathrm{VO}_{2 \text { peak }}$ and $\sim 91 \% \mathrm{FC}_{\text {peak }}$ over the training period. Conclusion: The proposed protocol produced adaptations and intensities which are similar to those described in the literature, but unlike others, it can be applied in sporadically active individuals. Level of Evidence Il; Comparative prospective study.
\end{abstract}

Keywords: High-intensity interval training; Physical Endurance; Lipid Metabolism.

\section{RESUMO}

Introdução: O treinamento cardiorrespiratório intervalado de alta intensidade (high-intensity interval training, HIT) tem sido utilizado como alternativa ao treinamento cardiorrespiratório contínuo de intensidade submáxima e duração prolongada. Objetivo: Propor um protocolo de HIT utilizando corrida em esteira e verificar a influência de seis sessões de HIT com esse protocolo sobre os limiares anaeróbios ventilatórios (LAVS) e o padrão de oxidação de substratos durante o exercício contínuo de intensidade submáxima (ECIS). Métodos: Quinze indivíduos irregularmente ativos foram submetidos, antes e após seis sessões de HIT com corrida em esteira, a teste progressivo máximo para determinação do pico de consumo de oxigênio $\left(V_{2} O_{2 p i c d}\right)$, velocidade de pico ( $\left.V_{\text {picc }}\right)$ e $L A V$ s seguidos de ECIS para determinação das taxas de oxidação de lipídios (LIPOX) e carboidratos (CHOox). As sessões de HIT eram compostas por oito séries de 60 segundos a 100\% Vico com 75 segundos de recuperação passiva entre as séries e com 48 horas de intervalo entre as sessões. Resultados: Observaram-se aumentos das intensidades de ocorrência dos LAVs (4,4\% para LAV1 e 8,8\% para LAV2), redução de 12,8\% de CHOox e aumento de 23,7\% de LIPox; Como consequência, a energia relativa derivada de LIPox apresentou-se 20,3\% maior após o período de treinamento. A $V_{\text {pico }}$ foi de $\sim 15 \mathrm{~km} / \mathrm{h}$, promovendo intensidades correspondentes a $\sim 84 \% \mathrm{VO}_{2 \text { pico }}$ e $\sim 91 \% F C_{\text {pico }}$ ao longo do período de treinamento. Conclusão: O protocolo proposto promoveu adaptações e intensidades similares às descritas na literatura; porém, ao contrário de outros, é passivel de aplicação em indivíduos irregularmente ativos. Nível de Evidência ll; Estudo prospectivo comparativo.

Descritores: Treinamento intervalado de alta intensidade; Resistência Física; Metabolismo dos Lipídeos.

\section{RESUMEN}

Introducción: El entrenamiento cardiorrespiratorio intermitente de alta intensidad (high-intensity interval training, HIT) ha sido utilizado como alternativa al entrenamiento cardiorrespiratorio continuo de intensidad submáxima y duración prolongada. Objetivo: Proponer un protocolo de HIT utilizando carrera en cinta y verificar la influencia de seis sesiones de HIT con ese protocolo sobre los umbrales anaeróbicos ventilatorios (UAVs) y el patrón de oxidación de substratos durante el ejercicio continuo de intensidad submáxima (ECIS). Métodos: Quince individuos irregularmente activos fueron sometidos, antes y después de seis sesiones de HIT con carrera en cinta, a test progresivo máximo para determinación del pico de consumo de oxígeno $\left(\mathrm{VO}_{2 p i c a}\right)$, velocidad de pico ( $V_{\text {pico }}$ y UAVs seguidos de ECIS para determinación de las tasas de oxidación de lípidos (LIPOX) y carbohidratos (CHOox). Las sesiones de HIT eran compuestas por ocho series de 60 segundos a 100\% $\mathrm{V}_{\text {pico }}$ con 75 segundos de recuperación pasiva entre las series y con 48 horas de intervalo entre las sesiones. Resultados: Se observaron aumentos de las intensidades de ocurrencia de los UAVs (4,4\% para UAV1 y 8,8\% para UAV2), reducción de 12,8\% de CHOox y aumento de 23,7\% de LIPox; como consecuencia, la energía relativa derivada 
de LIPox se presentó 20,3\% mayor después del período de entrenamiento. La $V_{\text {pico }}$ fue de $\sim 15 \mathrm{~km} / \mathrm{h}$, promoviendo intensidades correspondientes a $\sim 84 \% \mathrm{VO}_{2 \text { pico }}$ e $\sim 91 \% \mathrm{FC}_{\text {pico }}$ a lo largo del período de entrenamiento. Conclusión: El protocolo propuesto promovió adaptaciones e intensidades similares a las descritas en la literatura; sin embargo, al contrario de otros, es pasible de aplicación en individuos irregularmente activos. Nivel de Evidencia Il; Estudio prospectivo comparativo.

Descriptores: Entrenamiento de intervalos de alta intensidad; Resistencia Física; Metabolismo de los Lípidos.

\section{INTRODUCTION}

Cardiorespiratory endurance, which is expressed by oxygen consumption $\left(\mathrm{VO}_{2}\right)$, is one of the most important components of physical fitness. ${ }^{1}$ Training increases mitochondrial oxidative activity, pulmonary diffusion, and hemoglobin saturation, optimizing the oxidation of lipids (LIP), the reduction in muscle synthesis of lactic acid, and the accumulation of lactate and hydrogen ions in the blood. ${ }^{2,3}$

Different protocols for cardiorespiratory exercise (CrE) have been proposed to optimize the use of fatty acids (FA), since low rates of lipid oxidation may be involved with the development of excess weight, type II diabetes, and cardiovascular diseases ${ }^{4}$.

High-intensity interval training (HIT), characterized by short periods of vigorous activity interspersed with periods of rest or low intensity exercise, ${ }^{5}$ has been used as an alternative to traditional cardiorespiratory training (TCT), which is performed continuously at submaximal intensity and for a prolonged duration. Recent studies have observed similar or greater adaptations promoted by HIT, regarding muscle oxidative activity, ${ }^{7-9}$ use of energy substrates during or after the exercise $e^{6,7,9-11}$ and cardiovascular function ${ }^{6,12,13}$ among others, suggesting potential implications related to the health, including type II diabetes, overweight/obesity, and cardiovascular disease, ${ }^{6,14}$ in addition to the obvious increase in performance. ${ }^{13,15.16}$

However, most HIT studies use cycle ergometry protocols derived from the Wingate test. ${ }^{15}$ Training protocols with these characteristics require, in addition to a specialized ergometer, an extremely high motivation level of the subjects, and given the extreme nature of the exercise, it is questionable whether the general population can adopt this model in a safe and practical manner. ${ }^{6}$

Thus, the objectives of this study were: a) to propose an alternative HIT protocol using a treadmill, as the literature presents different training protocols using cycle ergometry as the predominant model, (b) assess the influence of six HIT sessions of treadmill running on the intensities in which the ventilatory anaerobic thresholds (LAVs) occur, and c) on the substrate oxidation pattern during continuous exercise of submaximal intensity (CESI, 45 min of treadmill running at the intensity of the first ventilatory anaerobic threshold, LAV1).

\section{MATERIALS AND METHODS}

All procedures were submitted to and approved by the Ethics Committee for Research Involving Human Subjects of the Cidade de São Paulo
University (CAAE 31998914.8.0000.0064), and all subjects signed an Informed Consent Form. The experiment was conducted in the Laboratory of Physiology and Metabolism of the Cidade de São Paulo University.

The study involved 15 men who were irregularly active according to their $I P A Q$, were non-smokers, and were not using any medication or nutritional ergogenic substance during the study period. The mean values \pm standard error for age, weight, height, body fat percentage and peak oxygen consumption $\left(\mathrm{VO}_{2 \text { peak }}\right)$ relative to the total body mass of subjects were $25.8 \pm$ 1.2 years, $72.3 \pm 1.4 \mathrm{~kg}, 175.2 \pm 2.1 \mathrm{~cm}, 16.3 \pm 0.9 \%$, and $42,5 \pm 1.3 \mathrm{~mL} / \mathrm{kg} /$ min, respectively. The subjects were instructed to maintain their number of daily meals, type of food consumed, and preparation throughout the study.

After clinical evaluation, the subjects were tested to determine their $\mathrm{VO}_{\text {2peak }}$ peak velocity $\left(\mathrm{V}_{\text {peak }}\right)$, and LAVs. Two days after the completion of the initial evaluations, the subjects were submitted to CESI to determine rates of lipid (LIPOx) and carbohydrate (CHOox) oxidation, after 4 hours of food restriction followed by ingestion of maltodextrin $(1 \mathrm{~g} / \mathrm{kg}$, $12 \%$ solution), 30 min before the start of the training. Subsequently, the subjects underwent six sessions of HIT with 48-h intervals between the sessions. At the end of the training period, the subjects were again tested for determination of $\mathrm{VO}_{2 \text { peak }} \mathrm{V}_{\text {peak }}$ and LAVs, and were submitted to new CESI to determine the rates of LIPOx and CHOox under the same conditions cited above. (Figure 1)

Prior to the determination of $\mathrm{VO}_{2 \text { peak, }}$, the subjects remained lying and rested for $10 \mathrm{~min}$ to determine ventilatory data and initial heart rate (HR). The test protocol consisted of running on a treadmill (ATL Model, Inbrasport Ltda., Brazil) with an initial velocity of $6 \mathrm{~km} / \mathrm{h}$, followed by increasing increments of $1 \mathrm{~km} / \mathrm{h}$ every minute until voluntary exhaustion of the subjects.

The ventilatory parameters were collected at rest and continuously throughout the tests, at each respiratory cycle and analyzed at an average of 20 sec through a computerized gas analyzer (VO2000; Inbrasport Ltda, Brazil). The gas analyzer was calibrated to a standard volume and to the concentration of gases immediately before the first test of the day and re-calibrated after each test, according to the standardization of the manufacturer. The HR was recorded using a cardiac monitor (model Sport Test; Polar Electro Oy, Finland), continuously throughout the tests. After exhaustion, there were two recovery periods of two min each, with $50 \%$ and $25 \%$ of the highest speed reached. Only HR was monitored during the recovery periods.

\begin{tabular}{|c|c|c|c|c|}
\hline $\begin{array}{l}\mathrm{VO}_{2 \text { peak }} \\
\text { LAVs }\end{array}$ & $\begin{array}{c}\text { ECIS } \\
\text { Fasting }(4 \mathrm{~h}) \\
1 \mathrm{~g} / \mathrm{kg} \mathrm{Malto}(30 \mathrm{~min}) \\
45 \text { min LAV1 }\end{array}$ & 6 HIT sessions & $\begin{array}{l}\mathrm{VO}_{2 \text { peak }} \\
\text { LAVs }\end{array}$ & $\begin{array}{c}\text { ECIS } \\
\text { Fasting }(4 \mathrm{~h}) \\
1 \mathrm{~g} / \mathrm{kg} \text { Malto }(30 \mathrm{~min}) \\
45 \text { min LAV1 }\end{array}$ \\
\hline $\begin{array}{c}\text { Session } 1 \\
\text { Day } 1\end{array}$ & $\begin{array}{l}\text { Session } 2 \\
\text { Day } 3\end{array}$ & $\begin{array}{c}\text { Sessions } 3 \text { to } 8 \\
\text { Days } 5 \text { to } 15\end{array}$ & $\begin{array}{c}\text { Session } 9 \\
\text { Day } 17\end{array}$ & $\begin{array}{l}\text { Session } 10 \\
\text { Day } 19\end{array}$ \\
\hline
\end{tabular}

Figure 1. Experimental study. 
The criteria for the determination of $\mathrm{VO}_{2 \text { peak }}$ and exhaustion were as follows: occurrence of a plateau in $\mathrm{VO}_{2}$ (characterized by increases of 2 $\mathrm{mL} / \mathrm{kg} / \mathrm{min}$ or less) and the inability to maintain the velocity, respectively. The $V_{\text {peak }}$ corresponded to the highest velocity reached during the test.

The LAVs were determined from the ventilatory equivalents $\left(\mathrm{VENO}\right.$, and $\left.\mathrm{VE} / \mathrm{NCO}_{2}\right)$, end expired fractions $\left(\mathrm{FEO}_{2}\right.$ and $\left.\mathrm{FECO} \mathrm{C}_{2}\right)$, and respiratory quotient (RQ) and expressed as a function of $\mathrm{VO}_{2}(\mathrm{~mL} / \mathrm{kg} / \mathrm{min})$. LAV1 corresponded to the lowest value of $\mathrm{VE} / \mathrm{NO}_{2}$ before its continued rise associated with the beginning of the abrupt change and the continued increase of the RQ. LAV2 corresponded to the point at which the non-linear increases of $\mathrm{VENO}, \mathrm{VE} / \mathrm{NCO}_{2}$, and $\mathrm{FEO}_{2}$ coincided with the fall of $\mathrm{FECO}_{2}{ }^{17}$.

Before and after the training period, the subjects performed 45 min of CrE at the intensity of LAV1 (pre and post-training CESI) after 4 hours of food restriction followed by ingestion of maltodextrin ( $1 \mathrm{~g} / \mathrm{kg}, 12 \%$ solution), 30 min before the start of the activity. The purpose of food restriction and ingestion of $\mathrm{CHO}$ before the CESI sessions was to enable similar metabolic states among subjects during the experimental sessions. Ventilatory parameters were collected during rest and continuously over the CESI, at each respiratory cycle, and analyzed in averages of 20 sec by a computerized gas analyzer (model VO2000; Inbrasport Ltda, Brazil) to determine LIPox and CHOox rates.

The rates of LIPox and CHOox were determined in blocks of 10 min throughout the CESI, from mean values of $\mathrm{VO}_{2}$ and $\mathrm{VCO}_{2}$ (L/min), corresponding to the last two min of each block. Oxidation rates (in $\mathrm{g} / \mathrm{min}$ ) were calculated using Frayn's ${ }^{18}$ stoichiometric equations, assuming an insignificant nitrogen excretion rate. The energy provided by LIPox and CHOox (LIPkc and CHOkc, respectively, in $\mathrm{kcal} / \mathrm{min}$ ) was calculated from their respective energy equivalents ( 9.75 and $3.87 \mathrm{kcal} / \mathrm{g}$ for LIP and $\mathrm{CHO}$, respectively).

The subjects underwent six HIT sessions, with 48-h intervals between sessions. The HIT protocol of treadmill running consisted of two initial warm-up periods ( 2 min each, $25 \%$ and $50 \% \mathrm{~V}_{\text {peak }}$ ), followed by eight series of $60 \mathrm{sec}$ at $100 \% \mathrm{~V}_{\text {peak }}$ for $75 \mathrm{sec}$ of passive recovery, two final slowing periods ( 2 min each, at $50 \%$ and $25 \% V_{\text {peak }}$ ). Ventilatory parameters and $\mathrm{HR}$ were measured in each training session to determine the relative effort intensity.

\section{Statistical analysis}

Results are presented as mean \pm standard error. The homogeneity of the variances was verified by the Levene test. Ventilatory parameters, $H R$, running velocity, and oxidation rates of the experimental sessions were compared using the Student's t-test or Sign test for paired data. The relative intensities of effort between training sessions and running series were compared through single-factor analysis of variance, followed by the Tukey HSD post-hoc test. The level of significance was set at $p$ $<0.05$. Statistical analysis was performed using the Statistica for Windows software (version 8.0, 2007, Statsoft, Inc., United States).

\section{RESULTS}

No significant differences were observed between the absolute pre and post-training values at the peak effort in $\mathrm{VO}_{2}, \mathrm{HR}$, and velocity (Table 1).

The six training sessions led to an increase in the intensities of the occurrence of the $L A V$ s, relative to the $V_{2}$ peak of $4.4 \%$ for $L A V 1(p=0.23)$ and $8.8 \%$ for $L A V 2(p=0.01)$. Discrete increases were observed but were not significant for $H R$ and velocity in the intensities of the LAVs, relative to $\mathrm{VO}_{\text {2peak }}$. (Table 2)

The mean pre- and post-training $\mathrm{RQ}$ and substrate oxidation values are presented in Table 3. After the training sessions, there was a reduction of $12.8 \%$ of CHOox ( $p=0.01)$ and an increase of $23.7 \%$ in LIPox ( $p=0.04)$. As a result, the relative energy derived from the LIPox (Figure 2) was
20.3\% higher after the training period $(29.2 \pm 2.5$ to $35.1 \pm 2.2 \% \mathrm{kcal} / \mathrm{min}$, pre and post-training, respectively; $p=0.01$ ).

The $V_{\text {peak }}$ was $14.9 \pm 0.4 \mathrm{~km} / \mathrm{h}$, leading to relative intensities of 83.8 $\pm 0.6 \% \mathrm{VO}_{2 \text { peak }}$ and $91.4 \pm 0.2 \% \mathrm{FC}_{\text {peak }}$ with training. No significant differences were observed among the six training sessions (s) for $\% \mathrm{VO}_{2 \text { peak }}$ and $\% \mathrm{FC}_{\text {peak }}$ (Figures 3 and 4, respectively).

No significant differences were observed between the eight running bouts (c) for $\% \mathrm{VO}_{2 \text { peak }}$ (Figure 5); however, the \% $\mathrm{FC}_{\text {peak }}$ presented significant differences on comparison between the initial and final series (Figure 6).

Table 1. Maximal test: absolute values for performance parameters.

\begin{tabular}{c|c|c|c|c}
\hline & & $\begin{array}{c}\mathbf{V O}_{2} \\
(\mathbf{m L} / \mathbf{k g} / \mathbf{m i n})\end{array}$ & $\begin{array}{c}\text { HR } \\
(\mathbf{b p m})\end{array}$ & $\begin{array}{c}\text { VEL } \\
(\mathbf{k m} / \mathbf{h})\end{array}$ \\
\hline \multirow{2}{*}{ LAV1 } & Pre & $20.4 \pm 0.5$ & $130.0 \pm 3.2$ & $7.1 \pm 0.2$ \\
\cline { 2 - 5 } & Post & $20.9 \pm 1.8$ & $127.3 \pm 2.7$ & $7.3 \pm 0.2$ \\
\hline \multirow{2}{*}{ LAV2 } & Pre & $30.9 \pm 0.9$ & $165.9 \pm 3.8$ & $10.7 \pm 0.4$ \\
\cline { 2 - 5 } & Post & $32.8 \pm 2.6$ & $162.3 \pm 3.0$ & $11.0 \pm 0.3$ \\
\hline \multirow{2}{*}{ PEAK } & Pre & $42.4 \pm 1.2$ & $191.4 \pm 2.9$ & $14.9 \pm 0.4$ \\
\cline { 2 - 5 } & Post & $40.6 \pm 3.1$ & $187.5 \pm 2.5$ & $15.3 \pm 0.4$ \\
\hline
\end{tabular}

Mean values \pm standard error; $n=15$. LAV1, first ventilatory anaerobic threshold; LAV2, second ventilatory anaerobic threshold; $M X$, peak effort capacity; $\mathrm{VO}_{2}$, oxygen consumption; $\mathrm{HR}$, heart rate; $\mathrm{VEL}$, velocity.

Table 2. Maximal test: values relative to the effort peak for performance parameters.

\begin{tabular}{c|c|c|c|c}
\hline \multirow{2}{*}{} & & $\begin{array}{c}\text { VO }_{2} \\
(\%)\end{array}$ & $\begin{array}{c}\text { HR } \\
(\%)\end{array}$ & $\begin{array}{c}\text { VEL } \\
\text { (\%) }\end{array}$ \\
\hline \multirow{3}{*}{ LAV1 } & PRE & $48.5 \pm 1.5$ & $67.9 \pm 1.1$ & $47.9 \pm 0.8$ \\
\cline { 2 - 5 } & POST & $50.7 \pm 1.8$ & $68.7 \pm 1.5$ & $48.8 \pm 0.9$ \\
\hline \multirow{2}{*}{ LAV2 } & PRE & $73.0 \pm 1.3$ & $86.6 \pm 1.1$ & $71.7 \pm 1.5$ \\
\cline { 2 - 5 } & POST & $79.4 \pm 1.5^{\mathbf{A}}$ & $87.0 \pm 1.3$ & $73.1 \pm 1.8$ \\
\hline \multirow{3}{*}{$\Delta \%$} & LAV1 & 4.4 & 1.3 & 1.8 \\
\cline { 2 - 5 } & LAV2 & $8.8^{\mathbf{B}}$ & 0.5 & 1.9 \\
\hline
\end{tabular}

Mean values \pm standard error; $n=15$. LAV1, first ventilatory anaerobic threshold; LAV2, second ventilatory anaerobic threshold; $\Delta \%$, relative variation; $\mathrm{VO}_{2}$, oxygen consumption; $\mathrm{HR}$, heart rate; $\mathrm{VEL}$, velocity. ${ }^{\mathrm{A}}$ indicates $p<0.05 \mathrm{vs}$. Pre. ${ }^{\mathrm{B}}$ indicates $p<0.05$.

Table 3. Oxidation of substrates between the training periods.

\begin{tabular}{c|c|c|c}
\hline & & CHOox & LIPox \\
\hline ECIS & RQ & $(\mathrm{g} / \mathrm{min})$ & $(\mathrm{g} / \mathrm{min})$ \\
\hline PRE & $0.91 \pm 0.01$ & $1.71 \pm 0.06$ & $0.28 \pm 0.02$ \\
\hline POST & $0.89 \pm 0.01^{\mathrm{A}}$ & $1.49 \pm 0.05^{\mathrm{A}}$ & $0.34 \pm 0.02^{\mathrm{A}}$ \\
\hline$\triangle \%$ & $-2.2^{\mathrm{B}}$ & $-12.8^{\mathrm{B}}$ & $23.7^{\mathrm{B}}$ \\
\hline
\end{tabular}

Mean values \pm standard error: $n=15$. CESI, continuous exercise of submaximal intensity: $R Q$ re spiratory quotient; $\mathrm{CHOox}$, oxidation of carbohydrates; LIPox, oxidation of lipids; $\Delta \%$, relative variation. ${ }^{\mathrm{A}}$ indicates $\mathrm{p}<0.05$ vs. PRE; ${ }^{\mathrm{B}}$ indicates $\mathrm{p}<0.05$.

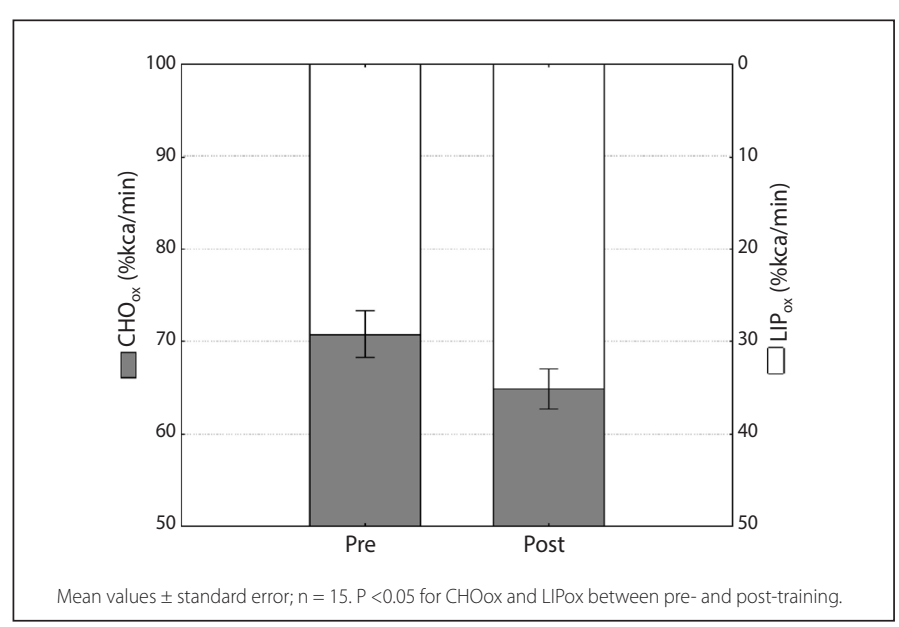

Figure 2. Relative contribution of $\mathrm{CHO}$ and LIP to caloric expenditure. 


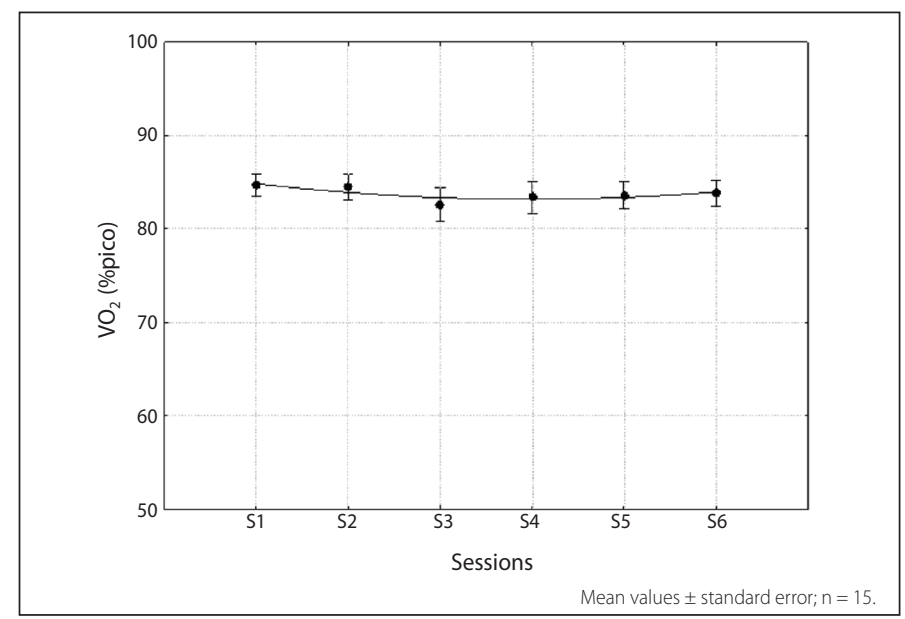

Figure 3. Effort intensities relating to peak oxygen consumption: training sessions.

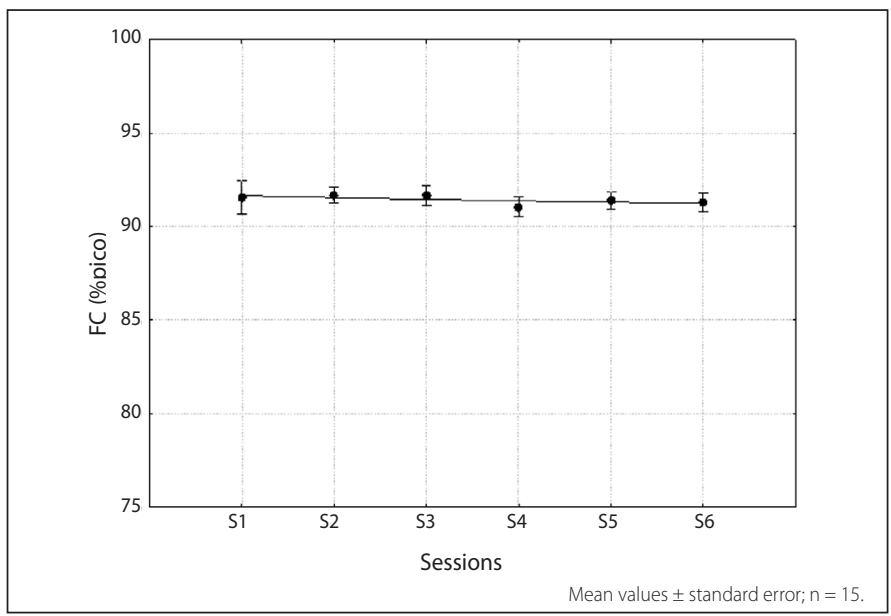

Figure 4. Effort intensities related to peak heart rate: training sessions.

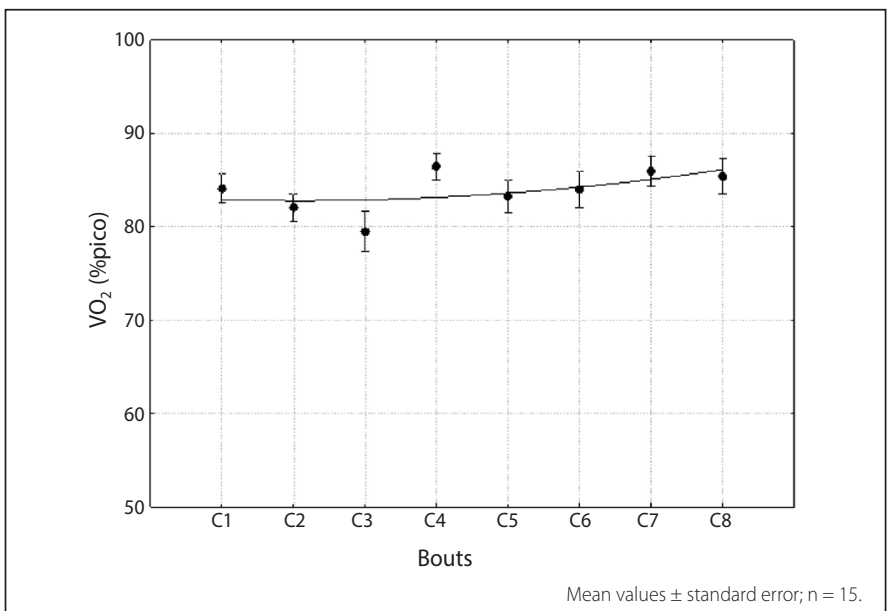

Figure 5. Effort intensities related to peak oxygen consumption: running series,

\section{DISCUSSION}

The objectives of this study were to verify the influence of HIT sessions with a treadmill running protocol on the LAVs and oxidation pattern of substrates during CESI. Our results showed changes in the intensities of the LAVs and increased oxidation and contribution of LIP to maintain energy demand during CESI after six running sessions on a treadmill, composed by eight series of $60 \mathrm{sec}$ at $100 \% \mathrm{~V}_{\text {peak }}$ with $75 \mathrm{sec}$ of passive recovery.

Published reports have consistently demonstrated that regular cardiorespiratory endurance training enhances the performance of tasks

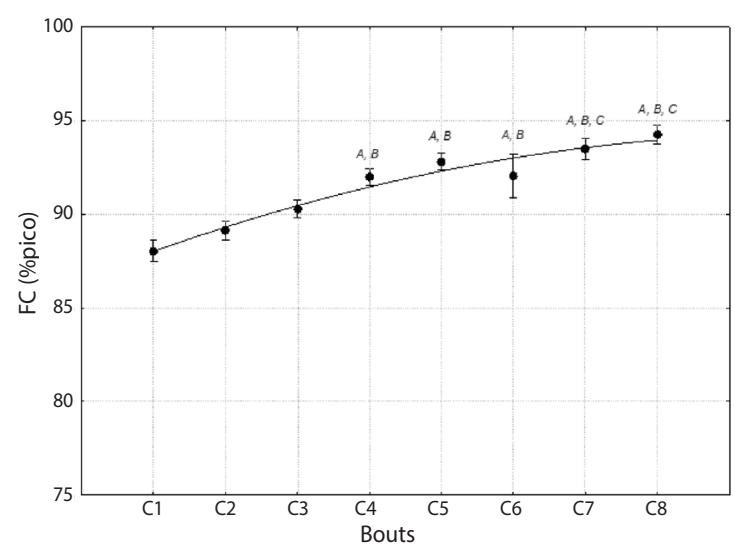

Mean values \pm standard error; $n=15$. A indicates $p<0.05$ vs. C1; B indicates $p<0.05$ vs. C2 C indicates $p<0.05$ vs. C3.

Figure 6. Effort intensities relative to peak heart rate: running series

that depend fundamentally on oxidative energy metabolism, due in large part to an increase the capacity of skeletal muscles in transporting and using $\mathrm{O}_{2}$ and LIP. For this reason, different $\mathrm{CrE}$ protocols have been proposed to optimize the use of FA, since low rates of LIPox may be involved with the development of those who are overweight or have type II diabetes and cardiovascular diseases ${ }^{19}$.

Several studies have reported significant differences in responses during the recovery period after exercise depending on the mode of execution of the CrE associated with its effort intensity. Kaminsky et al.. ${ }^{20} \mathrm{Bahr}$ \& Sejersted ${ }^{21}$, and Borsheim \& Bahr ${ }^{22}$ observed greater magnitude and duration of EPOC promoted by $\mathrm{CrE}$ conducted in periods of vigorous activity interspersed with periods of low intensity exercise, implying a higher caloric expenditure and LIPox. On the other hand, during physical activity, LIPox is directly related to the intensity of exercise performed. Published studies, for example, indicate intervals of intensity for maximum LIPox between $44-49 \%$ of $\mathrm{VO}_{2 \max }$ and $60-64 \%$ of $\mathrm{HR}_{\text {max }}{ }^{23,24}$ in other words, at intensities close to LAn1.

However, the majority of studies involving HIT cycle ergometry use protocols derived from the Wingate tes ${ }^{15}$, with maximum repeated efforts. Little et al., ${ }^{25}$, for example, used a cycle ergometry protocol comprising 4 sets of $30 \mathrm{sec}$ each with a load of $0.075 \mathrm{~kg} / \mathrm{kg}$ body mass at maximum speed and with 4 min of passive rest between sets. Training protocols with these characteristics require, in addition to a specialized ergometer, an extremely high level of motivation of the subject, and given the extreme nature of the exercise, it is questionable whether the population may adopt this model in a safe and practical manner. ${ }^{6}$

Accordingly, different studies have proposed alternative HIT protocols involving maximum or above maximum effort levels. In a previous study Little et al. ${ }^{8}$, observed that eight to twelve series of cycle ergometry for $60 \mathrm{sec}$ with approximately $350 \mathrm{~W}$, interspersed by $75 \mathrm{sec}$ with $30 \mathrm{~W}$ promoted effort intensities compatible with adaptations promoted by cycle ergometry protocols derived from the Wingate test. When comparing calisthenics exercises with cycle ergometry similar to the Wingate test, Gist et al. ${ }^{26}$ observed that four series of $30 \mathrm{sec}$ with the highest number of possible repetitions of calisthenic exercise promoted similar intensities to the cycle ergometry protocol, around $80 \% \mathrm{VO}_{2 \text { peak }}$ and $85 \% \mathrm{FC}$ peak. Weston et al. ${ }^{15}$ report mean intensities of $85-95 \% \mathrm{FC}_{\text {peak }}$ for HIT training for the general population, suggesting a classification based on these intensities to characterize different interval exercise protocols such as HIT.

In accordance with the literature, our results suggest that the treadmill running protocol leads to a high-enough intensity to characterize it as 
high intensity; however, unlike others, this protocol can be applied in untrained physically active individuals.

The change in performance capability and the pattern of oxidation of substrates promoted by the HIT can be explained by the increase of the muscular oxidative activity and use of energy substrates, during or after the exercise, among others. Talanian et al. ${ }^{10}$ observed a change in the pattern of oxidation of substrates in physically active women subjected to seven HIT sessions on a cycle ergometer (10 sets of 4 min at $90 \% \mathrm{VO}_{2 \text { peak }}$ with 2 min rest between sets) over 13 days. Perry et al. ${ }^{11}$ found the same adaptations when reproducing the protocol described above in untrained active men for six weeks. In a later study, Talanian et al. ${ }^{7}$ found that training with this protocol increased the levels of sarcoplasmic and mitochondrial FA transporters (FAT/ CD36 and FABPpm) and increased oxidative enzyme activity, which are adaptations responsible for the increase of LIPOx and changing the pattern of oxidation of substrates. Little et al. ${ }^{8}$ found that after six HIT sessions on a cycle ergometer (8 to 12 series of $60 \mathrm{sec}$ at $100 \%$ of the maximum load with 75 sec to recover $10 \%$ of the maximum load between series), there was a stimulus of mitochondrial biogenesis due to the increased content of PGC-1a (peroxisome proliferator-activated receptor $y$ co-activator $1 a$ ); this adaptation was also observed after a single HIT session with 4 sets of $30 \mathrm{sec}$ with $0.075 \mathrm{~kg} / \mathrm{kg}$ at the maximum speed with 4 min of rest between series. ${ }^{25}$

The adjustments indicated above, along with an increase of the sarcoplasmic and mitochondrial FA transporters together with mitochondrial biogenesis, potentiate LIPox in detriment of the use of $\mathrm{CHO}^{27}$ and may be the probable mechanism of interference of HIT in the oxidation of substrates. ${ }^{23,24,27}$

\section{CONCLUSION}

Our results suggest, in agreement with the literature, that the proposed protocol leads to intensities sufficient to characterize it as high intensity; however, unlike others, this can be applied in untrained physically active individuals.

Our results also indicate that six HIT sessions with a treadmill running protocol promotes changes: (a) in the intensities of the occurrence of $L A V$ s, expressed in function of the $\mathrm{VO}_{2}$, especially for $\mathrm{LAV} 2$, and (b) in the pattern of oxidation of substrates, while running at submaximal intensity with increased oxidation and contribution of LIP to maintain the energy demand.

All authors declare no potential conflict of interest related to this article

AUTHORS' CONTRIBUTIONS: Each author made significant individual contributions to this manuscript. MLM (0000-0002-6593-941X)*: preparation of the entire research project, data analysis, drafting of the article and review; CFMA (0000-0002-0036-2103)* and FRL (0000-0002-9710-0803)*: training sessions, data collection and review; JMLA (0000-0003-2859929X)*: experimental design, training sessions, data collection and review; MSC (0000-0001-7667-9492)*: training sessions and data collection. All authors approved the final version of the manuscript. *ORCID (Open Researcher and Contributor ID).

\section{REFERENCES}

1. American College of Sports Medicine. ACSM's Guidelines for Exercise Testing and Prescription, (9th ed.). Baltimore: Williams \& Wilkins, 2014. ISBN 978-1-60913-605-5.

2. Holloszy JO, Coyle EF. Adaptations of skeletal muscle to endurance exercise and their metabolic consequences. J Appl Physiol Respir Environ Exerc Physiol. 1984;56(4):831-8.

3. Sahlin K. Control of lipid oxidation at the mitochondrial level. Appl Physiol Nutr Metab. 2009;34(3):382-8.

4. Pruchnic R, Katsiaras A, He J, Kelley DE, Winters C, Goodpaster BH. Exercise training increases intramyocellular lipid and oxidative capacity in older adults. Am J Physiol Endocrinol Metab. 2004;287(5):E857-62.

5. Gibala MJ, Little JP, Macdonald MJ, Hawley JA. Physiological adaptations to low-volume, high-intensity interval training in health and disease. J Physiol. 2012;590(5):1077-84.

6. Levine J, Melanson EL, Westerterp KR, Hill JO. Measurement of the componentes of nonexercise activity thermogenesis. Am J Physiol Endocrinol Metab. 2001;281(4):E670-5.

7. Talanian JL, Holloway GP, Snook LA, Heigenhauser GJ, Bonen A, Spriet LL. Exercise training increases sarcolemmal and mitochondrial fatty acid transport proteins in human skeletal muscle. Am J Physiol Endocrinol Metab. 2010;299(2):E180-8

8. Little JP, Safdar A, Wilkin GP, Tarnopolsky MA, Gibala MJ. A practical model of low-volume high-intensity interval training induces mitochondrial biogenesis in human skeletal muscle: potential mechanisms. J Physiol. 2010;588(Pt 6):1011-22.

9. Scribbans TD, Edgett BA, Vorobej K, Mitchell AS, Joanisse SD, Matusiak JB, et al. Fibre-specific responses to endurance and low volume high intensity interval training: striking similarities in acute and chronic adaptation. PLoS One. 2014;9(6):e98119.

10. Talanian JL, Galloway SD, Heigenhauser GJ, Bonen A, Spriet LL. Two weeks of high-intensity aerobic interval training increases the capacity for fat oxidationduring exercise in women. J Appl Physiol. 2007;102(4):1439-47.

11. Perry CG, Heigenhauser GJ, Bonen A, Spriet LL. High-intensity aerobic interval training increases fat and carbohydrate metabolic capacities in human skeletal muscle. Appl Physiol Nutr Metab. 2008;33(6):1112-23.

12. McKay BR, Paterson DH, Kowalchuk JM. Effect of short-term high-intensity interval training vs. continuous training on $\mathrm{O} 2$ uptake kinetics, muscle deoxygenation, and exercise performance. J Appl Physiol (1985). 2009;107(1):128-38.

13. Roxburgh BH, Nolan PB, Weatherwax RM, Dalleck LC. Is moderate intensity exercise training combined with high intensity interval training more effective at improving cardiorespiratory fitness than moderate intensity exercise training alone? J Sports Sci Med. 2014;13(3):702-7.

14. Alvarez C, Ramirez-Campillo R, Martinez-Salazar C, Mancilla R, Flores-Opazo M, Cano-Montoya
J, et al. Low-volume high-intensity interval training as a therapy for type 2 diabetes. Int J Sports Med. 2016;37(9):723-9.

15. Weston KS, Wisløff U, Coombes JS. High-intensity interval training in patients with lifestyle-induced cardiometabolic disease: a systematic review and meta-analysis. Br J Sports Med. 2014;48(16):1227-34.

16. Milanović Z, Sporiš G, Weston M. Effectiveness of high-intensity interval training (hit) and continuous endurance training for $\mathrm{VO} 2$ max improvements: a systematic review and meta-analysis of controlled trials. Sports Med. 2015;45(10):1469-81.

17. Binder RK, Wonisch M, Corra U, Cohen-Solal A, Vanhees L, Saner H, et al. Methodological approach to the first and second lactate threshold in incremental cardiopulmonary exercise testing. Eur J Cardiovasc Prev Rehabil. 2008;15(6):726-34.

18. Frayn KN. Calculation of substrate oxidation rates in vivo from gaseous exchange. J Appl Physiol Respir Environ Exerc Physiol. 1983;55(2):628-34.

19. Goodpaster BH, Wolf D. Skeletal muscle lipid accumulation in obesity, insulin resistance, and type 2 diabetes. Pediatr Diabetes. 2004;5(4):219-26.

20. Kaminsky LA, Padjen S, LaHam-Saeger J. Effect of split exercise sessions on excess post-exercise oxygen consumption. Br J Sports Med. 1990;24(2):95-8.

21. Bahr R, Sejersted OM. Effect of intensity of exercise on excess postexercise $\mathrm{O} 2$ consumption. Metabolism. 1991;40(8):836-41.

22. Børsheim E, Bahr R. Effect of exercise intensity, duration and mode on post-exercise oxygen consumption. Sports Med. 2003;33(14):1037-60.

23. Chenevière X, Borrani F, Droz D, Gojanovic B, Malatesta D. Effects of 2 different prior endurance exercises on whole-body fat oxidation kinetics: light vs. heavy exercise. Appl Physiol Nut Metab. 2012;37(5):955-64

24. Rynders CA, Angadi SS, Weltman NY, Gaesser GA, Weltman A. Oxygen uptake and ratings of perceived exertion at the lactate threshold and maximal fat oxidation rate in untrained adults. Eur J Appl Physiol. 2011;111(9):2063-8.

25. Little JP, Safdar A, Bishop D, Tarnopolsky MA, Gibala MJ. An acute bout of high-intensity interval training increases the nuclear abundance of PGC-1a and activates mitochondrial biogenesis in human skeletal muscle. Am J Physiol Regul Integr Comp Physiol. 2011 ;300(6):R1303-10.

26. Gist NH, Freese EC, Cureton KJ. Comparison of responses to two high-intensity intermittent exercise protocols. J Strength Cond Res. 2014;28(11):3033-40.

27. Jeppesen J, Kiens B. Regulation and limitations to fatty acid oxidation during exercise. J Physiol. 2012;590(5):1059-68. 